\title{
ZONING OF THE URBAN ENVIRONMENT BY THE LEVEL OF SOIL POLLUTION AND ITS IMPACT ON THE FORMATION OF RISKS TO PUBLIC HEALTH
}

\author{
E.R. Valeeva ${ }^{1}$ (D) G.A. Ismagilova ${ }^{1}$ (D), N.V. Stepanova ${ }^{1}$ (D) A.I. Ziyatdinova ${ }^{2}$ (D), \\ I.A. Kiyasov² (iD, K.K. Ibragimova ${ }^{2}(\mathbb{D})$, A.R.Ilyasova ${ }^{2}$ (D)
}

${ }^{1}$ Department of Bioecology, Hygiene and Public Health, Institute of Fundamental Medicine and Biology, Kazan Federal University, Kazan, Russia (420008, Kazan, K. Marx street, 76)

${ }^{2}$ Department of Human Health, Institute of Fundamental Medicine and Biology, Kazan Federal University, Kazan, Russia (420008, Kazan, K. Marx street, 76)

Received - September 25, 2020; Revision - November 16, 2020; Accepted - December 14, 2020

Available Online December 15, 2020

DOI: http://dx.doi.org/ 10.18006/2020.8(Spl-2-AABAS).S354.S360

\section{KEYWORDS \\ Soil, Priority Pollutants \\ Non-Carcinogenic Risk \\ Health}

Adolescents

\begin{abstract}
The priority pollutants of urban soils are oil products, nitrates, cadmium, and zinc. The total noncarcinogenic risk was higher in the Kirovsky and Vakhitovsky districts of the city, and the dermal path was the most significant among the chemical penetration pathways. The distribution of risk factors for adolescent health along the path of inhalation was determined for the various critical target organs such as kidneys, hormones, blood, and respiratory systems. Analysis of the content of total metals in the soils of different districts showed that copper, zinc, lead made the major contribution to pollution in the calculation according to MAC $(\mathrm{Zc})$ in all districts. Nitrates remain an important contaminant in every city under study. The values of total pollution factor, both for total and mobile forms of metals, did not exceed 16 units allowing placing the samples under study into a category with allowable contamination. The content of mobile forms of metals (apart from cadmium) did not exceed regulations in all selected zones. However, according to the results of our research, the concentrations of mobile forms of metals exceeded the concentrations of total forms of the same metals by approximately two times (but stayed within the limits of MAC).
\end{abstract}

* Corresponding author

E-mail: val_med@mail.ru (E.R. Valeeva)

Peer review under responsibility of Journal of Experimental Biology and Agricultural Sciences.

Production and Hosting by Horizon Publisher India [HPI] (http://www.horizonpublisherindia.in/).

All rights reserved.
All the articles published by Journal of Experimental Biology and Agricultural Sciences are licensed under a Creative Commons Attribution-NonCommercial 4.0 International License Based on a work at www.jebas.org.

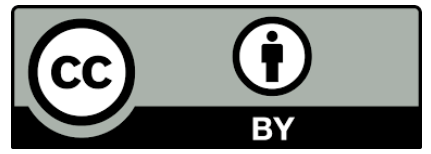




\section{Introduction}

Chemical safety is a priority task of any state development program (Rakhmanin \& Sinitsyna, 2013; Novikov \& Unguryanu, 2014; May, 2013). Nowadays the globality of ecological problems requires modern approaches to assessing the situation, which results from the anthropogenic load in large cities due to industrial technogenic emissions and accumulation of various pollutants in soils. The level of population health becomes highly correlated with intensity, duration of pollutant effects and degree of human adaptation to the living environment. Children and adolescents are most exposed to such effects (Stepanova et al., 2015; Behbod et al., 2016).

The state of soil is critical for the assessment of the ecological status of the city of Kazan, in particular, because the soil is sensitive to the anthropogenic impact. An important feature of the soil is the fact that it lacks the property of rapid selfpurification and restoration, and chemicals remain in it for many years. Polluted soil can be a source of secondary pollution of the atmospheric air, the surface and underground waters, foods of vegetable and animal origin and thereby have an impact on the ecologo-hygienic environment on the whole (Ivanov et al., 2012; Novikov \& Unguryanu, 2014; Rusakov, 2016; Novikov et al., 2016). At present, heavy metals (HM) have become an obvious ecological factor. The city soils undergo irreversible changes due to the urbanization process. The metals, which accumulate in the soil, are removed slowly on leaching, plant consumption, erosion, and deflation. National priorities should be set based on a regional assessment of the health-related chemical safety aspects, most of all the questions that arise in quality control of the environmental compartments (drinking water, foods, soils) (Whitmee et al., 2015; Wołejko et al., 2016; Novikov et al., 2017; Moysés \& Soares, 2019; Hanfi et al., 2020).

Health risk assessment is a method and basis to predict possible consequences of the chemical pollutant effects and make decisions to protect the vulnerable populations, upon which many International Environmental Organizations like WHO, FAO/WHO, the UN Commission, the European Union, WTO rely. Determining priorities in this field can facilitate the reduction of the burden of noncommunicable diseases of the adult and child population and increase of the population life expectancy. National priorities should be determined based on a regional assessment of the health-related aspects of chemical safety, in particular, emerging issues on the quality control of environmental objects. This study aims to assess the noncarcinogenic health risk of adolescents in the city of Kazan for the subsequent substantiation of recommendations for its reduction.

\section{Materials and Methods}

In the current study we analyzed the data obtained from 2004 to 2018 in the course of carrying out socio-hygienic monitoring and performed based on FSFHI "Center for Hygiene and Epidemiology in RT". Soil tests were taken per GOST 17.4.3.01, "Methodological proposals for leading field and research facility investigations of soils and plants in the control of natural contamination by metals" and "Brief rules for observing soil contamination" utilizing the "envelope" technique, for purposes of "the rudimentary" site from a profundity of $10 \mathrm{~cm}$. The choice of examining focuses was controlled by the area of the road transport organization of local locations, endeavors and the correspondence to the inspecting focuses. The selected test soil was ground in a huge porcelain mortar and sieved through a nylon sifter with an entire measurement of 1 $\mathrm{mm}$. Non-filtered pieces of soil were ground and sieved once more. Examination tests were taken from the acquired dirt. The substance of HM (hefty metals) in the dirt was dictated by nuclear ingestion examination dependent on RD 52.18.191-89 after MU "Technique for estimating the mass portion of corrosive dissolvable types of metal (copper, lead, zinc, nickel, and cadmium) in soil tests by nuclear assimilation investigation". The soil samples were collected from the territories of increased risk of impact on the population health such as the residential areas, children's pre-school, school, and medical institutions. MAC or TAC of chemical substances approved as hygienic standards became the major criterion for assessing the degree of soil contamination with these chemicals. The soils, in which the amounts of contaminants are at the level of MAC or higher, refer to the category of "contaminated". The characteristic of contaminations is performed based on the total pollution index $(\mathrm{Zc})$. The total pollution index $(\mathrm{Zc})$ characterizes the effect of exposure to a group of elements. As for sanitary and hygienic conditions, the soils of the city territories are broken down into categories according to the level of chemical contamination: clean, allowable, moderately hazardous, hazardous, and extra-hazardous. The exceedance of MAC is not allowed for the "clean" category of the soil contamination: To decide the substance of HM in the dirt, the strategies for nuclear assimilation spectrometry, inductively coupled plasma nuclear discharge spectrometry, and IR-spectroscopy are used in work. The mobile forms of metals are extracted by various extragents depending on the type of soils under study and the metal properties. Acids, various salts, buffer solutions, bidi stilled water are used as extragents. The methodology is as follows: ammonium acetate buffer solution is poured into the selected weighed quantity. The soil samples are damped and mixed in it. Then they are allowed to stand for 24 hours (with short-time stirring 5-7 times) at room temperature. After that the soil sample is filtrated, the filter is flushed with buffer solution, making the filtrate volume up to 100 $\mathrm{ml}$. And the content of the required elements is determined using an atomic absorption spectrometer (AAS). 
Table 1 An assessment scale for the levels of chemical pollution of soils and soils with heavy metals and arsenic according to the total pollution index (Zc) (according to GN 2.1.7.2041-06 and GN 2.1.7.2511-09)

\begin{tabular}{|cc|}
\hline Soil pollution category & Value Zc \\
\hline Permissible & $<16$ \\
\hline Moderately dangerous & $16-32$ \\
\hline Dangerous & $32-128$ \\
\hline Extremely dangerous & $>128$ \\
\hline
\end{tabular}

Table 2 Current hygienic standards for soil pollution in the Russian Federation (according to GN 2.1.7.2041-06 and GN 2.1.7.2511-09)

\begin{tabular}{|cccccccc|}
\hline Regulations & $\mathrm{Cd}$ & $\mathrm{Cu}$ & $\mathrm{Ni}$ & $\mathrm{Pb}$ & $\mathrm{Zn}$ & $\mathrm{Co}$ & $\mathrm{Cr}$ \\
\hline $\begin{array}{c}\text { MPC (mg/kg - for mobile forms of elements in } \\
\text { the soil) }\end{array}$ & 0.1 & 3 & 4 & 6 & 23 & 5 & 6 \\
\hline
\end{tabular}

Table 3 Gross weighted average chemical content in soils in the territory of Kazan (mg/kg) (50\% and 95\% Percentile)

\begin{tabular}{|lccccccccc|}
\hline & \multicolumn{2}{c}{ Privolzhskiy } & \multicolumn{2}{c}{ Kirovskiy } & \multicolumn{2}{c}{ Sovetskiy } & \multicolumn{2}{c}{ Vakhitovskiy } \\
& $50 \%$ & $95 \%$ & $50 \%$ & $95 \%$ & $50 \%$ & $95 \%$ & $50 \%$ & $95 \%$ \\
\hline Ammonia (nitrogen) & 2.13 & 2.14 & 2.90 & 10.49 & 8.910 & 8.91 & 0.00 & 0.00 \\
\hline Nitrates (NO3) & 17.73 & 51.15 & 47.86 & 128.73 & 54.36 & 12.0 & 33.87 & 85.87 \\
\hline Elemental sulfur & 1.60 & 6.50 & 5.14 & 2.1 & 2.64 & 0.65 & 2.94 & 9.98 \\
\hline Sulfates & 4.49 & 19.46 & 15.38 & 6.39 & 7.19 & 11.35 & 8.37 & 29.64 \\
\hline Cadmium & 0.08 & 0.16 & 0.21 & 0.25 & 0.10 & 33.95 & 0.13 & 0.38 \\
\hline Arsenic & 0.00 & 0.00 & 0.00 & 0.00 & 0.00 & 0.34 & 0.00 & 0.00 \\
\hline Mercury & 0.01 & 0.00 & 0.01 & 0.09 & 0.00 & 0.00 & 0.01 & 0.00 \\
\hline Lead & 0.97 & 0.03 & 1.53 & 3.50 & 2.31 & 0.02 & 2.14 & 0.04 \\
\hline Copper & 0.62 & 1.95 & 0.63 & 1.86 & 1.67 & 4.69 & 1.15 & 5.88 \\
\hline Zinc & 3.13 & 1.35 & 6.15 & 16.03 & 8.32 & 3.26 & 5.22 & 2.15 \\
\hline Chlorides & 5.27 & 9.45 & 4.18 & 6.45 & 5.27 & 17.49 & 4.37 & 10.35 \\
\hline pH & 7.16 & 10.99 & 6.99 & 7.66 & 7.05 & 8.84 & 6.98 & 7.95 \\
\hline $\begin{array}{l}\text { Exchange } \\
\text { ammonium }\end{array}$ & 6.21 & 7.59 & 8.53 & 13.8 & 6.87 & 7.58 & 6.87 & 7.67 \\
\hline Oil products (total) & 322,99 & 756.13 & 445.2 & 951.0 & 376.4 & 831.7 & 444.82 & 940.88 \\
\hline
\end{tabular}

Evaluation of non-cancer-causing hazard due to air technogenic burden was done as per the "Rules for surveying general wellbeing hazard from presentation to synthetic compounds contaminating the climate" and incorporated the estimation of peril coefficients and records (R 2.1.10.1920-04))(R 2.1.10.1920-04, 2004).

\section{Results}

The total weighted average of chemicals in the soils on the territory of the city of Kazan was distributed in the following way (Table 3): the oil products ranked first (in the Vakhitovsky, Sovetsky, Kirovsky, and Privolzhsky districts - distribution in descending order), nitrates ranked second (in the Sovetsky,
Vakhitovsky, Kirovsky, and Privolzhsky districts - in descending order), sulphates ranked third (the Vakhitovsky, Kirovsky, Sovetsky and Privolzhsky districts correspondingly).

The high value of cadmium was identified only in the Sovetsky district (33.9). Presence of Zinc was reported from all the sampled districts of the city, but the indices were insignificant and different value was reported for different districts such as the Kirovsky (6.1), Sovetsky and Privolzhsky districts (3.2), and Vakhitovsky district of the city (2.1) completed the list. Various studies have shown that the accumulated significant amount of toxic waste increases the burden on the environment and creates a real threat to the health of the population. 
The problem of soil contamination with oil and oil products remains an urgent challenge under current conditions (Bekshin et al., 2015; Tafeeva et al., 2016). The result of the current study showed that the priority contaminant of the city soil was oil products (756.13-951.0) at the 95th perc level, where distribution according to city districts identified the leaders. They are Kirovsky and Vakhitovsky districts. It is found out that deterioration of the air and water regime, changes in structural properties of the soil take place in the oil-contaminated soils, and under these circumstances the content of mobile forms of microelements increases. An increase of the total amount of carbon takes place in the soil contaminated with oil and oil products, the proportion of non-hydrolyzed humus increases by more than 3 times, and this fact results in deterioration of soil fertility, a decrease of agricultural yield. As for soils contaminated with oil and oil products, the development of persistent restoration processes, which bring about a decrease in the soil biological activity, takes place in them, and it contributes to more rapid accumulation of unsaturated hydrocarbons and aggravation of sanitary status. These processes bring to deposition of toxic products (aldehydes, ketones, esters, alcohols, organic acids) in the soil and the increase of potential hazard of such soils.

Contamination of the soil with heavy metals is of particular danger (Soheil \& Mehrnaz, 2016; Solgi et al., 2017; Yang et al., 2018). Mobile heavy metals redistribute between separate components of the ecosystem accumulating in biomass of microorganisms and plants and are delivered into organisms of higher animals and the human body along trophic chains suppressing their biological activity and vital activities. Cadmium sulphates (0.10-33.95 at the 95th perc level) were identified in every district, but the highest level was registered in the Sovetsky district. In these circumstances, the increased prevalence of diabetes mellitus was observed in the districts contaminated with cadmium (Zhang et al.2018; Zhang et al., 2019). The incidence of adolescent and rheumatoid arthritis, diseases of the nervous system increased with zinc accumulation in cultivated soils. Results of the current study revealed the distribution of nitrates (51.15-128.73) and zinc (1.35-16.03) at the 95th percentile level, which indicated its presence in maximum values in the Kirovsky district of the city (Table 3). Accordingly, the appraisal results demonstrated that the dirt under investigation in discrete zones in the city of Kazan contrasted in different power of the component jumping on the dirt surface with technogenic outflows.

Comparative analysis of no-carcinogenic risk assessment among adolescents by different ways of entry showed that oil products made the most significant contribution to the risk, primarily with skin exposure (Tables 4, 5, and 6).

Table 4 Oral administration of chemicals with soil

\begin{tabular}{|c|c|c|c|c|c|}
\hline \multirow{2}{*}{ Chemical substance } & \multirow{2}{*}{$\begin{array}{l}\text { Reference dose } \\
\quad(\mathrm{mg} / \mathrm{m} 3)\end{array}$} & \multicolumn{4}{|c|}{$\mathrm{Mg} / \mathrm{kg}$ intake (per day) } \\
\hline & & Privolzhskiy & Kirovskiy & Sovetskiy & Vakhitovskiy \\
\hline Cadmium & $2.00 \mathrm{E}-05$ & 0 & 0 & 0.01 & 0.01 \\
\hline Mercury & 0.0003 & 0 & 0 & 0 & 0 \\
\hline Lead & 0.0005 & 0.04 & 0.07 & 0.09 & 0.12 \\
\hline Oil products (total) & 0.071 & 5.97 & 19.03 & 16.63 & 18.82 \\
\hline Copper & 0.00002 & 0.02 & 0.04 & 0.07 & 0.04 \\
\hline Nitrates (NO3) & 130 & 0.19 & 2.57 & 2.40 & 1.72 \\
\hline
\end{tabular}

Table 5 Non-carcinogenic oral health risk for adolescents

\begin{tabular}{|cccccc|}
\hline Chemical substance & $\begin{array}{c}\text { Reference dose } \\
(\mathrm{mg} / \mathrm{m} 3)\end{array}$ & Privolzhskiy & Kirovskiy & Sovetskiy & Vakhitovskiy \\
\hline Cadmium & $2.00 \mathrm{E}-05$ & 0.00002 & 0.00004 & 0.00005 & 0.00006 \\
\hline Mercury & 0.0003 & 0.00001 & 0.00002 & - & 0.00001 \\
\hline Lead & 0.0005 & 0.00004 & 0.00007 & 0.00010 & 0 \\
\hline Oil products (total) & 0.071 & 0 & 0.00235 & 0 & 0.00001 \\
\hline Copper & 0.00002 & 0.00001 & 0.00001 & 0.00001 & - \\
\hline Nitrates (NO3) & 130 & - & 0.00001 & 0.00001 & 0 \\
\hline
\end{tabular}

Journal of Experimental Biology and Agricultural Sciences http://www.jebas.org 
Table 6 Cutaneous injection of chemicals with soilHoe

\begin{tabular}{|cc|ccccc|}
\hline Chemical substance & $\begin{array}{c}\text { Reference dose } \\
(\mathrm{mg} / \mathrm{m} 3)\end{array}$ & Privolzhskiy & Kirovskiy & Sovetskiy & Vakhitovskiy \\
\hline Cadmium & $2.00 \mathrm{E}-05$ & 0 & 0 & 0.01 & 0.01 \\
\hline Mercury & 0.0003 & 0 & 0 & 0 & 0.09 \\
\hline Lead & 0.0005 & 0.04 & 0.07 & 16.63 & 18.82 \\
\hline Oil products (total) & 0.071 & 5.97 & 0.04 & 0.07 & 0.04 \\
\hline Copper & 0.00002 & 0.02 & 2.57 & 2.40 & 1.72 \\
\hline Nitrates (NO3) & 130 & 0.19 & & 0.03 \\
\hline
\end{tabular}

Table 7 Non-carcinogenic health risk for adolescents by city district with inhalation route of entry

\begin{tabular}{|lcccccc} 
Chemical substance & Reference dose $\left(\mathrm{mg} / \mathrm{m}^{3}\right)$ & Privolzhskiy & Kirovskiy & Sovetskiy & Vakhitovskiy \\
\hline Ammonia (nitrogen) & 0.1 & 0.00001 & 0.00003 & 0.00002 & - \\
\hline
\end{tabular}

Table 8 Total non-carcinogenic risk to adolescent health

\begin{tabular}{|cccccc|}
\hline Method of admission & Privolzhskiy & Kirovskiy & \multicolumn{2}{c|}{ Sovetskiy } & \multicolumn{2}{c|}{ Vakhitovskiy } \\
\hline cutaneous & 0.020 & 0.030 & 0.020 & 0.030 \\
\hline oral & 0.00008 & 0.0025 & 0.00017 & - \\
\hline inhalation & 0.00001 & 0.00003 & 0.00002 & 0.0302 \\
\hline Amount & 0.0202 & 0.0327 & 0.0204 & 0.03 \\
\hline
\end{tabular}

Table 9 The distribution of the values of the hazard coefficient for public health by city district (95\% Percentile)

\begin{tabular}{|ccccc|}
\hline Critical organs & Privolzhskiy & Kirovskiy & Sovetskiy & Vakhitovskiy \\
\hline Hormones & 0.000117 & 0.000168 & 0.000242 & 0.000436 \\
\hline OD & 0.000157 & 0.000073 & 0.000020 & 0.000154 \\
\hline Blood & 0.000180 & 0.000106 & 0.000179 & 0.000302 \\
\hline SSS & 0.000012 & 0.000005 & 0.000012 & 0.000009 \\
\hline Kidneys & 0.027626 & 0.025142 & 0.032787 & 0.025141 \\
\hline CNS & 0.000158 & 0.000095 & 0.000158 & 0.000287 \\
\hline HI & 0.02825 & 0.025589 & 0.033398 & 0.02632 \\
\hline
\end{tabular}

Higher dispersion of the risk remainder esteems for the juvenile wellbeing was uncovered for the kidneys, the respiratory framework, the blood, and the hormones. The risk of kidney diseases was identified in adolescents $(0.025142-0.032787)$, of the Kirovsky and Sovetsky districts correspondingly, at the level of the 95-th percentile of the hazard quotient. Hormones ranked second in the values of the risk of non-carcinogenic effects with high indices in the Privolzhsky and Vakhitovsky districts $(0.000157-0.000154)$. The risk for the blood diseases ranked third in general toxical effects of chemicals, high indices being observed in the Vakhitovsky district $(0.000179-0.000302)$ (Tables 8).
Hazard indices (HI) calculated from the median values of hazard coefficients were less than 1.0, indicating a low risk. By city districts, the highest total indexes are determined in the Soviet $(\mathrm{HI}=0.033398)$ and Privolzhsky districts $(\mathrm{HI}=0.02825)$ (Tables 9).

Based on the results of a comprehensive risk assessment in 4 zones of Kazan (according to the monitoring points: district Vakhitovsky ranked first while it was followed by Kirovsky, Sovetsky and Privolzhskiy districts respectively), it is shown that the value of the total non-carcinogenic risk (HI) for oral intake corresponds to the acceptable level (1.0 or less) (Tables 10).

Journal of Experimental Biology and Agricultural Sciences http://www.jebas.org 
Table 10 Comprehensive assessment of non-carcinogenic risk to adolescent health in multi-environmental exposure to soil chemicals

\begin{tabular}{|c|c|c|c|c|c|c|c|c|c|c|}
\hline $\begin{array}{c}\text { Way and } \\
\text { environment } \\
\text { of receipt }\end{array}$ & $\begin{array}{c}1 \text { zone } \\
\text { Vakhitovsky }\end{array}$ & $\begin{array}{c}2 \text { zone } \\
\text { Kirovsky }\end{array}$ & $\begin{array}{l}3 \text { zone } \\
\text { Sovetsky }\end{array}$ & $\begin{array}{c}4 \text { zone } \\
\text { Privolzhskiy }\end{array}$ & Сумма & $\begin{array}{c}1 \text { zone } \\
\text { Vakhitovsky }\end{array}$ & $\begin{array}{c}2 \text { zone } \\
\text { Kirovsky }\end{array}$ & $\begin{array}{c}3 \text { zone } \\
\text { Sovetsky }\end{array}$ & \multicolumn{2}{|c|}{4 zone } \\
\hline \multicolumn{11}{|c|}{ Inhalation route } \\
\hline Soil & 0.00002 & 0.00003 & 0.00004 & 0.00002 & 0.00011 & 18.18 & 27.27 & 36.36 & 18.18 & 100 \\
\hline \multicolumn{11}{|c|}{ Oral route } \\
\hline Soil & 0.00008 & 0.00008 & 0.00017 & 0.0025 & 0.0028 & 2.82 & 2.82 & 6.007 & 88.33 & 100 \\
\hline \multicolumn{11}{|c|}{ Dermal } \\
\hline Soil & 0.256 & 0.33 & 0.353 & 0.316 & 1.26 & 20.31 & 26.20 & 28.01 & 25.10 & 100 \\
\hline THI & 0.2561 & 0.33011 & 0.35321 & 0.31852 & 1.262 & 41.32 & 56.29 & 70.38 & 131.60 & \\
\hline
\end{tabular}

\section{Discussion}

The current study determined the total amount of average chemicals did not exceed the established hygienic normative. The detectable concentrations of oil products can become the cause of a change in physical and chemical characteristics of the soil, resulting in dysfunction of its self-purification processes, increase of the pollutants' stability in the soil deteriorating the ecologohygienic state of the soil on the whole (May 2013; Stepanova et al., 2015). The non-cancer causing wellbeing hazard for teenagers in the locale of the Kazan city with the cutaneous course of introduction varies with the district Privolzhsky (0.00003), Kirovsky (0.00004), Sovetsky, (0.00006), and Vakhitovsky (0.00006). An excess of the reference dose is observed for the cadmium element in all areas, but the highest was reported from the Vakhitovsky and Sovetsky districts. As indicated by measures for evaluating compound contamination the dirt of the city of Kazan alludes to the class of "clean" - the substance of synthetics in the dirt doesn't surpass the foundation one, yet it isn't higher than MAC (TAC) all things considered. The obtained results indicate the minimum risk level for adolescent health in the city irrespective of the living zone. Modern large cities are powerful sources of contaminants, which are included in regional migration cycles. Complex appraisal of the extent of the commitment of independent zones on the region of the city to the absolute danger esteem with the record of the multitude of courses of the synthetics' entrance recognized two zones: the third zone (Sovetsky area) and the fourth zone (Privolzhsky locale) positioning first in the danger level.

The gross substance of $\mathrm{HM}$ is one of the significant records applied during the investigation of synthetic contamination of soils. However, many studies show that the examination of the gross content of HM in the soils alone is insufficient. The account of the distribution of mobile forms in the soil, which can transit from solid phases to soil solutions and be absorbed by the living organisms, that is, they are the most active components of nutrition and pollution, is considered to be necessary.

\section{Conclusions}

The priority pollutants of urban soils are oil products, nitrates, cadmium, and zinc. The total non-carcinogenic risk was higher in the Kirovsky and Vakhitovsky districts of the city, and the dermal path was the most significant among the chemical penetration pathways. The distribution of risk factors for adolescent health along the path of inhalation was determined for the various critical target organs such as kidneys, hormones, blood, and respiratory systems.

Analysis of the content of total forms of certain metals in the soils of different districts showed that copper, zinc, lead made the major contribution to pollution in the calculation according to MAC $(\mathrm{Zc})$ in all districts. Nitrates remain the important contaminant in every city zone under study. The values of total pollution factor, both for total and mobile forms of metals, did not exceed 16 units allowing placing the samples under study into a category with allowable contamination. The content of mobile forms of metals (apart from cadmium) did not exceed regulations in all zones, which was selected. However, according to the results of the current study, the concentrations of mobile forms of metals exceeded the concentrations of total forms of the same metals by approximately two times (but stayed within the limits of MAC). So far, it is evident that solution to the problem of implementing assessment of the environmental quality, the soil, in particular, it is impossible without scientific justification and development of new assessment methods with the account of non-carcinogenic effects of chemicals, which should comply with a modern level of knowledge in the field of general scientific methodology for assessing population health risk. The impact and identification of actual contaminants in the conditions below the regulation level, their hazardous nature to the population health, and child and adolescent population, in particular, remains an important issue at present.

\section{Acknowledgments}

The work is performed by the Russian Government Program of Competitive Growth of Kazan Federal University. 


\section{Conflict of Interest}

Authors would hereby like to declare that there is no conflict of interests that could possibly arise.

\section{References}

Behbod B, Lauriola P, Leonardi G, Crabbe H, Close R, Staatsen B, Fletcher T, Knudsen LE, de Hoogh K, Medina S, et al. (2016) Environmental and public health tracking to advance knowledge for planetary health. European Journal of Public Health 26(6):900. doi: 10.1093/eurpub/ckw176.

Bekshin ZM, Turmukhambetova AA, Uzbekov VA, et al. (2015) Perepichko Soil as a source of environmental risks. Problems of rationing and monitoring the level of soil pollution with chemicals Medicine and Ecology 3(76): 42-47.

Solgi E, Khodadadi A, Galangashi MM (2017) Characterizing Changes of Heavy Metals in the Soils from Different Urban Location of Borujerd, Lorestan Province, Iran. Journal of Chemical Health Risks 7(3). DOI: 10.22034/JCHR.2017.544182.

Hanfi MY, Mostafa MYA, Zhukovsky MV (2020) Heavy metal contamination in urban surface sediments: sources, distribution, contamination control, and remediation. Environmental Monitoring and Assessment 192: 32 (2020). https://doi.org/10.1007/s10661-019-7947-5.

Ivanov VP, Vasilieva OV, Polonikov AV (2012) Scientific and methodological foundations of risk assessment for public health in a comprehensive environmental and hygienic study of territories. Human Ecology11: 11-16.

May IV (2013) Establishment and proof of harm to the health of a citizen caused by the negative impact of environmental factors. Public Health and the Environment 11 (248): 4-6.

Moysés S, Soares R (2019) planetary health in the Anthropocene Health Promotion International 34 (1):128-136.

Novikov SM, Fokin MV, Shashina TA, Dodina NS (2017) Tools for environmental risk assessment (TERA) Russian information and forecasting system: experience in health risk assessment. Hygiene and Sanitation 96 (11): 1088-1090. DOI: 10.18821/00169900-2017-96-9-868-874.

Novikov SM, Fokin MV, Unguryanu TN (2016) Actual issues of the methodology and development of evidence-based risk assessment of public health when exposed to chemicals. Gigiena $i$ sanitariia 95(8): 711-716.

Novikov SM, Unguryanu TN (2014) Assessment of the chemical effect on the working population in single-industry towns. Gigiena i sanitaria 95 (5): 74-78.
R 2.1.10.1920-04. Guidance on assessing public health risk from exposure to chemicals that pollute the environment. - M.: Federal Center for State Sanitary and Epidemiological Supervision of the Ministry of Health of Russia, 2004.143.

Rakhmanin IuA, Sinitsyna OO (2013) The state and updating of tasks to improve scientific, methodological and regulatory frameworks in the field of human ecology and environmental hygiene. Gigiena i sanitaria 95 (5): 4-10.

Rusakov NV (2016) Methodological problems of non-infectious epidemiology and hygiene during chemical environmental pollution. Hygiene and Sanitation 95 (9):797-800.

Soheil S, Mehrnaz G (2016) Analysis of Heavy Metals in Surface Sediments from Agh Gel Wetland, Iran. Iranian Journal of Toxicology10 (4): 41-46.

Stepanova NV, Valeeva ER, Fomina SF (2015) Approaches to ranking urban areas by the level of pollution with heavy metal. Gigiena i sanitariia 94(5):56-61.

Tafeeva EA, Ivanov AV, Titova AA, Petrov IV (2016) The content of heavy metals and oil products in the soil in the territory of oilproducing regions of the Republic of Tatarstan. Gigiena i sanitariia 95(10): 939-941.

Whitmee S, Haines A, Beyrer C, Boltz F, Capon AG, de Souza Dias BF, EzehA, Gong P, Head P, Horton R, et al. (2015) Safeguarding Human Health in the Anthropocene Epoch: Report of The Rockefeller Foundation-Lancet Commission on Planetary Health. Lancet 386:1973-2028.

Wołejko E, Wydro U, Łoboda T (2016) The ways to increase efficiency of soil bioremediation. Ecological Chemistry and Engineering 23(1): 155-174.

Yang Q, Li Z, Lu X, Duan Q, Huang L, Bi J (2018) A review of soil heavy metal pollution from industrial and agricultural regions in China: pollution and risk assessment. Science of the Total Environment 642:690-700.

Zhang Q, Han G, Liu M, Li X, Wang L, Liang B (2019) Distribution and Contamination Assessment of Soil Heavy Metals in the Jiulongjiang River Catchment, Southeast China. International Journal of Environmental Research and Public Health 16: 4674.

Zhang Y, Liu YR, Lei P, Wang YJ, Zhong H (2018) Biochar and nitrate reduce risk of methylmercury in soils under straw amendment. The Science of the Total Environment 619-620:384390 . 